\title{
Designing a Community Forum Information System Using Web-Based RAD Method
}

\author{
Nasril Sany ${ }^{1}$, Achmad Rachmat $\mathbf{S}^{2}$, Anggie Grace $\mathbf{N}$ Harefa ${ }^{3}$ \\ Universitas Raharja ${ }^{1,2,3}$ \\ Jl. Jenderal Sudirman No.40, Cikokol, Kota Tangerang, Banten \\ e-mail: nasril.sany@raharja.info ${ }^{1}$, achmad.rachmat@raharja.info² ${ }^{2}$, anggie.grace@raharja.info
}

To cite this document:

sany, nasril, s, achmad rachmat, \& n harefa, anggie grace. (2020). Designing a Community

Forum Information System Using Web-Based RAD Method. IAIC Transactions on

Sustainable Digital Innovation (ITSDI), 2(1), 11-22.

DOI : https://doi.org/10.34306/itsdi.v2i1.24

\begin{abstract}
Nowadays it is inevitable in the development of the necessities of life, information technology that meets the requirements. There are programs that are made from a computer in making software. Community is a group of people who have the same taste and vision. The problem issued by the community is the large number of media that can accommodate every activity that can inform and can be seen by many people. Very limited media information provided is less updated and maintenance costs are very expensive compared via the website. Social communities are in dire need of information that supports and provides satisfying services for donors. Then a web-based community information system design was made. This design uses the RAD method. The stages of this RAD are covering information needs and interface requirements. Design phase of the interface design itself. This information system is designed to provide solutions as problems that exist in the community with a computerized system to be developed.
\end{abstract}

Keywords: RAD, Community, Website.

\section{Introduction}

Information systems science is very important for someone who has a high priority in an organization or community, because with a good understanding then implemented on the information system will have a positive impact on the organization or community in terms of competitiveness and achieving good goals. Information systems and technology have become a vital tool for an organization in terms of creating innovation in the best service areas, as well as new business models.

Knowledge of information system technology is needed for organizations and companies in the dissemination of information media, because it is crucial that the role of information encourages an organization or community to create an appropriate information system to facilitate the work and activities of parties in order to obtain the information needed from the organization or community These, both from the top level management to the level of low level management and those outside the organization or community. The information 
system of an organization or community that will be discussed by the author, namely the social community.

The social community has several types of activities as a means of engaging and facilitating helping people who are very disadvantaged in their lives to be exposed more widely and can be assisted by donors and volunteers from various groups. As well as giving education to the general public in order to be able to give goodness to anyone without giving a reward.

Information about the activities of each community communication program has not been recorded digitally, that is, there are still some in the group that only contains members, and the data of each person who is donated is still not stored properly and often is lost because it is only in the form of screenshots. This certainly makes it difficult for donors and administrators of the social community itself when searching for information and data. Communities that have more than one year certainly have activities that have been carried out, but all of that has not been well recorded and is not digitally published.

From the description above, the author is motivated to make a digital information system in the form of a website that is easily accessed anywhere and anytime, not limited to tools because it can be used through smartphones and laptops and data is stored in an organized and well.

\section{Research Method}

Stages in this research method describe the stages of the process, methods and tools needed in conducting research so that research can run properly and smoothly for the achievement of objectives. In this study using the stages of the activity plan needs, design plans, study of literature and system design.

Requirement Planning $>$ Design System $>$ Impleentation

\subsection{Requirement Planning}

\section{Metod RAD}

Users and analysis meet to identify the goals of the system and information needs to achieve the goals. At this stage it is the main thing with the involvement of the second party.

At this stage the authors analyze the community information in terms of the distribution of donations and target information to be used as donations for general worthy things. This analysis aims to examine the problems that occur and the need for information systems in support of achieving goals. This analysis is based on data that has been obtained previously.

1. Creating concepts and models in the needs of this information system website by describing functions that produce data that will be processed into information using the Unified Modeling Language (UML) system design, the following steps are taken:

a. Determine the initial planning

This process is structured in terms of the agenda of what activities will be carried out.

b. Analyzing business processes

At this stage an analysis of the business processes contained in this community.

c. Analyzing the information system used today

At this stage an analysis of the information system that runs at this time.

d. Building a prototype of an information system

At this stage the system design is made using a user interface using Yii Framework application programming. 


\subsection{Literature Review}

- Research conducted by Tenia Wahyuningsih, and Dwi Januarita in 2014 from ST3 Telkom entitled " Perancangan WEB e-Commerce dengan Metode Rapid Application Development (RAD) untuk Produk Unggulan Desa ". This study describes a village that has a Community Information Group (KIM) that sells superior products to communities that cannot be marketed. Therefore, an e-commerce web was created to expand marketing reach and increase sales. The method used in this research is Rapid Application Development (RAD) with various stages.

- Research conducted by Ifan Sadewa and Kondar Siahaan in 2016 from STIKOM Dinamika Bangsa, entitled " Analisis dan Perancangan Sistem Informasi Unit Kegiatan Mahasiswa (UKM) Berbasis Web Pada Universitas Batanghari". This study describes the distribution of management information and membership in each UKM has not been digitally recorded, that is still on a sheet of decree paper or still conventionally. Therefore a web-based information system design was made.

- Research conducted by Bosker Sinaga in 2015 from STMIK Pelita Nusantara entitled "Perancangan dan Pembuatan Sistem Informasi Forum Diskusi Mahasiswa/l Berbasis Web Di STMIK Pelita Nusantara". This research explains about the absence of efficient and up-to-date information services for college students. Then made this system by giving theories that have been accepted by building websites using PHP and MySQL applications. Use data collection methods, design and build. So that the end does not need to be difficult in finding information that can spend a lot of time, money and energy. Providing fast service and updates can be accessed by anyone and at any time.

- Research conducted by Mochamad Triyono in 2018 from Muria Kudus University entitled " Sistem Informasi Komunitas Sosial Pada Omah Aksi DI Kabupaten Kudus Berbasis Web Responsif". This research describes the social community information system to manage in terms of product marketing, scheduling activities and sharing among community members. Which focuses on Omah action for formal and non formal education by producing products in the form of crafts. The method used in the analysis and design of systems with an object-oriented approach using UML.

- Research conducted by Kadek Yogi Saputra, I Made Arsa Suyadnya and Ida Bagus Alit Swamardika in 2016 from Udayana University entitled " Rancangan Bangun Aplikasi Komunitas Donor Darah Berbasis Web dan Android Dilengkapi Layanan Info Geografis". This study describes the Blood Stock at PMI (Indonesian Red Cross) which is difficult to get blood donors. Then an application was made to be able to share information related to blood donors by using features that can make it easier for users to find blood donor information. The method used is data collection and system testing. The results of this research system can provide information on blood requirements and blood donor activities quickly. 


\subsection{Design Plan}

In designing the system that will be proposed, the writer makes a design that is designed using UML (Unified Modeling Language) which consists of use cases.

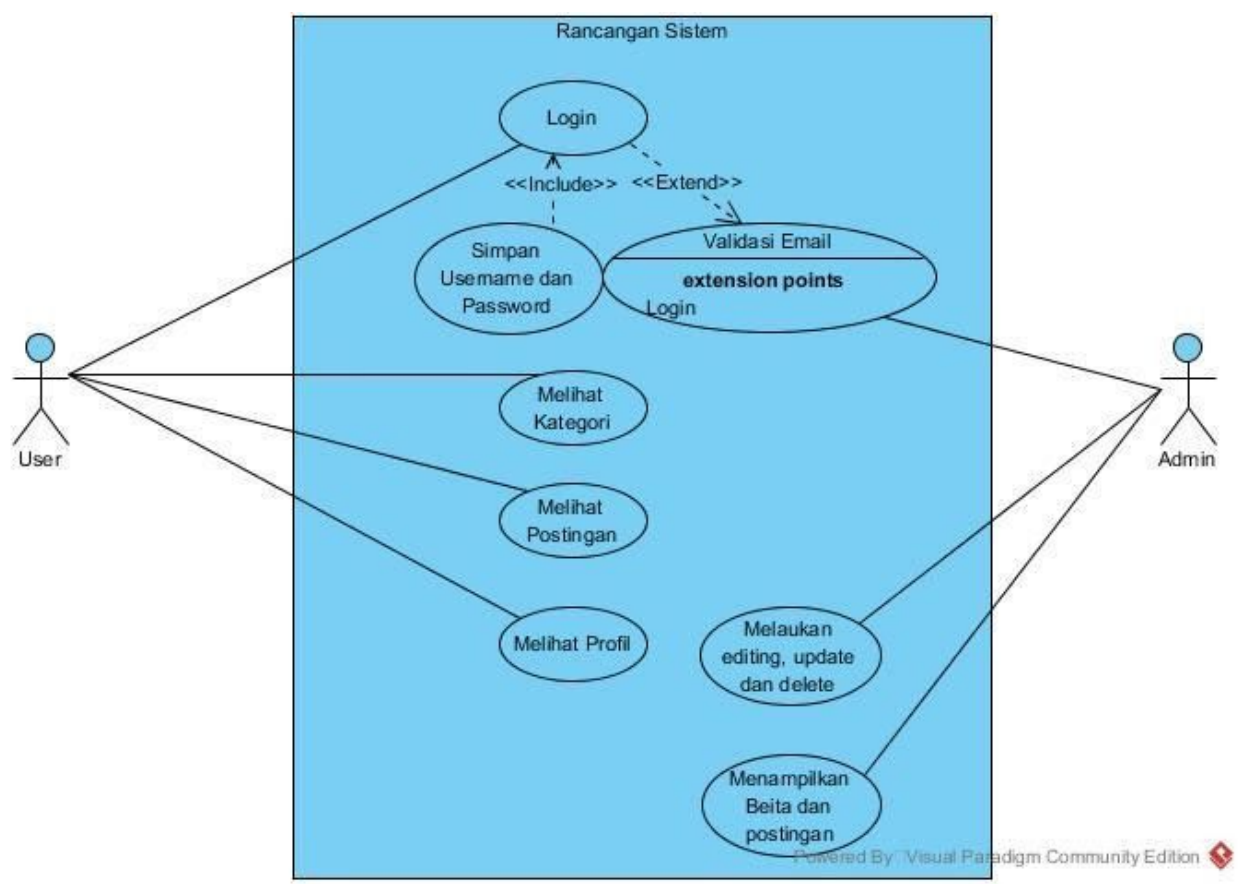

Figure 1. Use Case Design

Based on the description of the use case design above, an explanation can be given as follows:

a. Consists of two actors namely user and admin

b. There is a system that covers the whole

c. Consists of eight activities which are divided into two categories

\subsection{System Functional Requirements}

This is the stage to describe the functional modeling of the system to be designed. The functions that must be done by the system to serve the needs of users. Based on the needs of visitors, members and admins, the main functions to be carried out by this information system are as follows:

1. User
a. Information View Function
Intended to be able to see information about activities that are being done or that have been done, as well as news of the latest info related to social activities.
b. Search function
Used by users to search for information based on only certain desires by typing a keyword.
c. Login and Register Functions 
Used to enter the system and if you do not have access, the user can register to get an account for the requirements to enter the system.

d. Comment function

2. Admin

Used for users can give suggestions and enter.
a. Manage Access Functions
Addressed by the admin in the form of answering input and suggestions from users.
b. Login function
Enabled to be able to access the system
c. Manage function
Used by the admin to carry out the process of adding, updating, editing and deleting.
d. Function of Making Reports
This function is used to create and print reports, document the results of activities, and reports on the use of funds on activities.

\section{Findings}

\subsection{Problem}

The background of this research is based on the management of the social community in carrying out operational activities conventionally and in distributing information is still inefficient because they have to spend a lot of time. The documentation of each activity is not published and not updated in the delivery often loses data. And the flow process that is currently running is still not well organized.

Table 1. User Analysis

\begin{tabular}{|l|l|}
\hline \multicolumn{1}{|c|}{ Category } & \multicolumn{1}{c|}{ User } \\
\hline Main Needs & $\begin{array}{l}\text { Can communicate virtually, can access activity reports, can view } \\
\text { reports of donation funds, can share information with each other } \\
\text { and give advice and input }\end{array}$ \\
\hline Main Problems & $\begin{array}{l}\text { Difficult to communicate, there is no information system, } \\
\text { document data is always lost and not organized properly and } \\
\text { correctly, reporting is still conventional. }\end{array}$ \\
\hline $\begin{array}{l}\text { Problem solving } \\
\text { strategy }\end{array}$ & $\begin{array}{l}\text { By using the RAD method, it can produce data-based data } \\
\text { access and communication services. }\end{array}$ \\
\hline
\end{tabular}

\subsection{Research Implementation}

This information system website will be designed in the hope that it will run after it is implemented in order to provide benefits. In designing this information system, software as a design media is needed.

\subsubsection{Website Display Design}

1. Home Page Design 


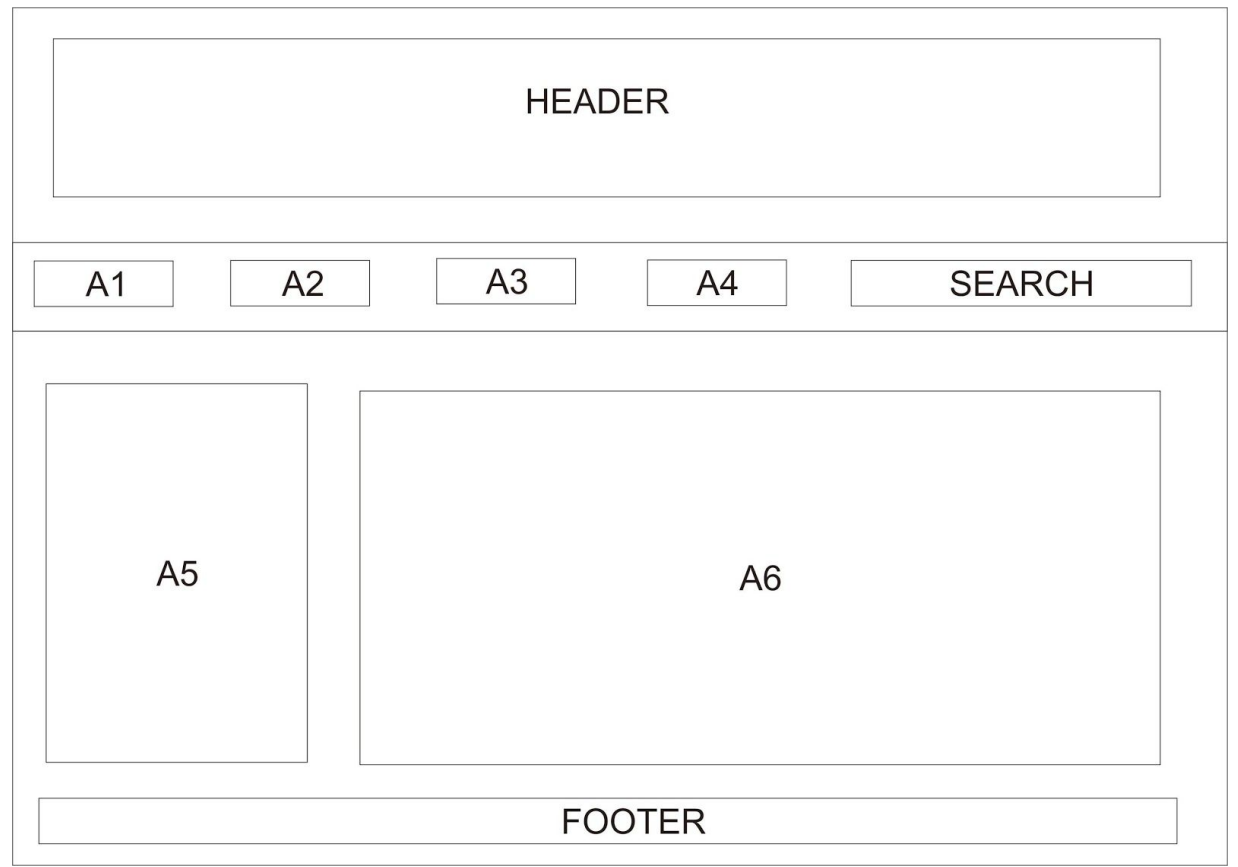

Figure 2. Home Page Design

In this picture is the front page of everything on the website. Or bias is also called the opening page because when this website is opened the first time this page appears. Information:

A1. Homepage, Main web page

A2. About, this page contains information about the community and the history of its establishment.

A3. Profile, page about photos of social activities.

A4 Activities, this page contains information about donation activities.

A5. Donations, this page contains reports on donation funds and donation payments. A6 Posts, this page contains about the target posts that will be open donations. 
2. Activity Page Design

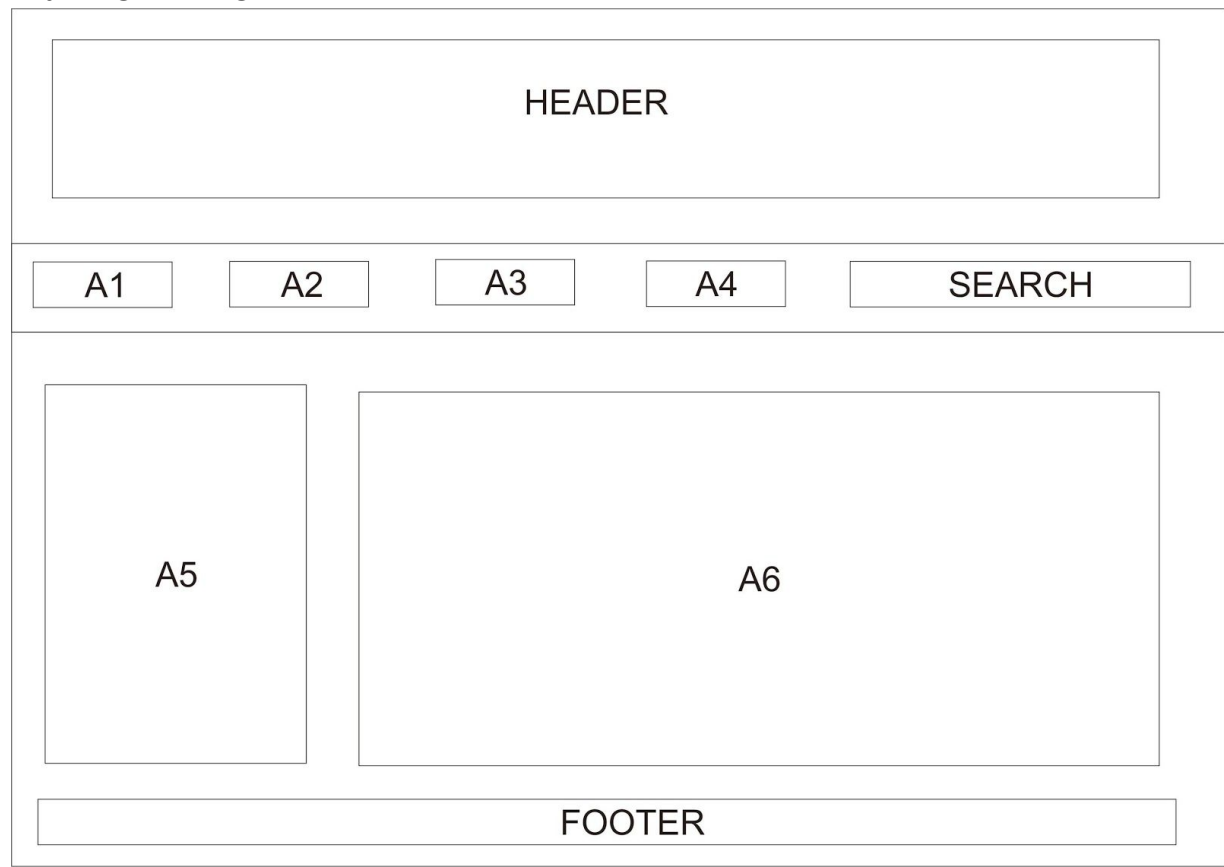

Figure 3. Activity Page Design

In this picture, it explains about the activities in which there are articles of activities that have been carried out or that are being carried out.

Information:

A1. Homepage, Main web page

A2. About, this page contains information about the community and the history of its establishment.

A3. Profile, page about photos of social activities.

A4 Activities, this page contains information about donation activities.

A5. Donations, this page contains reports on donation funds and donation payments.

A6 Posts, this page contains about the target posts that will be open donations. 
3. Entrance Page Design

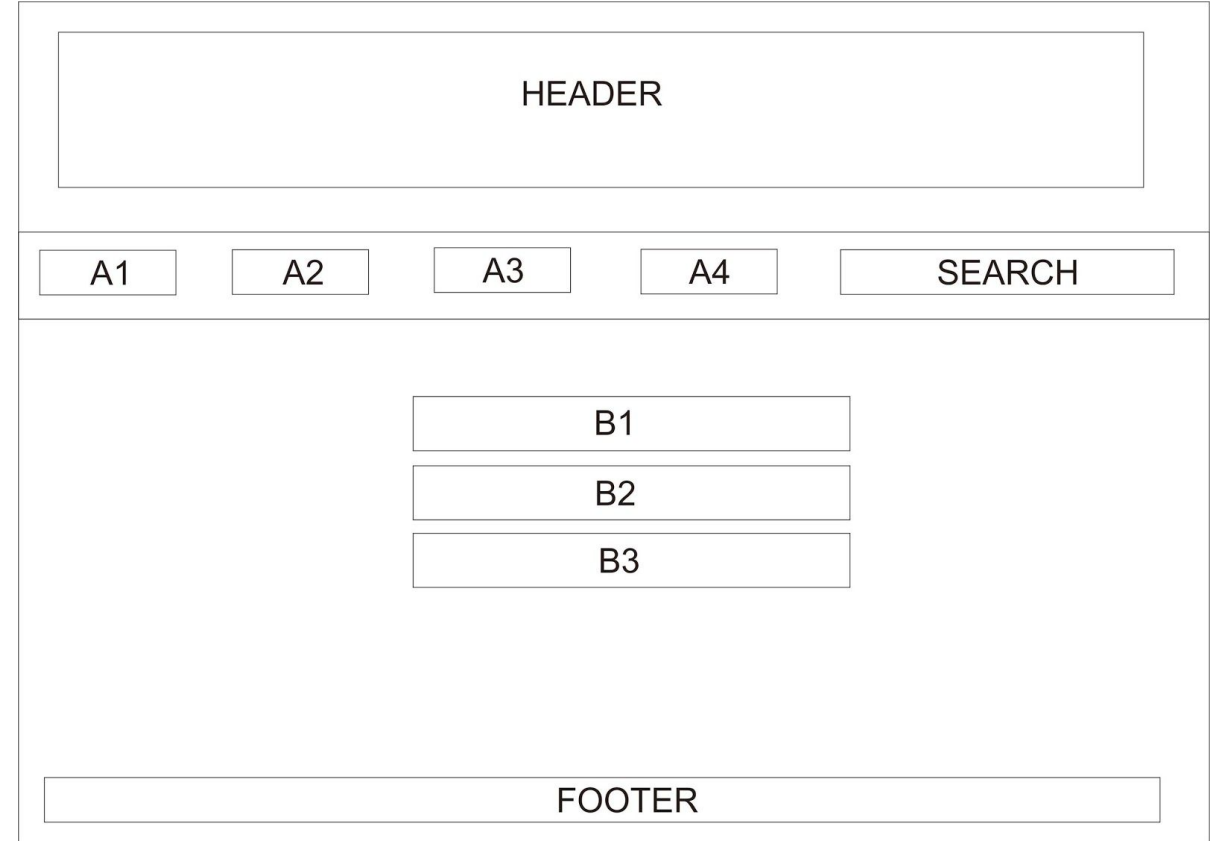

Figure 4. Entry Page Design

The login page and website are pages that are meant to be able to access the system by the administrator. To access this page, the admin must log in with the account that was created when registering by entering your email and password.

In this picture, it explains about the activities in which there are articles of activities that have been carried out or that are being carried out.

Information:

A1. Homepage, Main web page

A2. About, this page contains information about the community and the history of its establishment.

A3. Profile, page about photos of social activities.

A4 Activities, this page contains information about donation activities.

B1. E-mail

B2. The password

B3. Login 
4. Registration Page Design

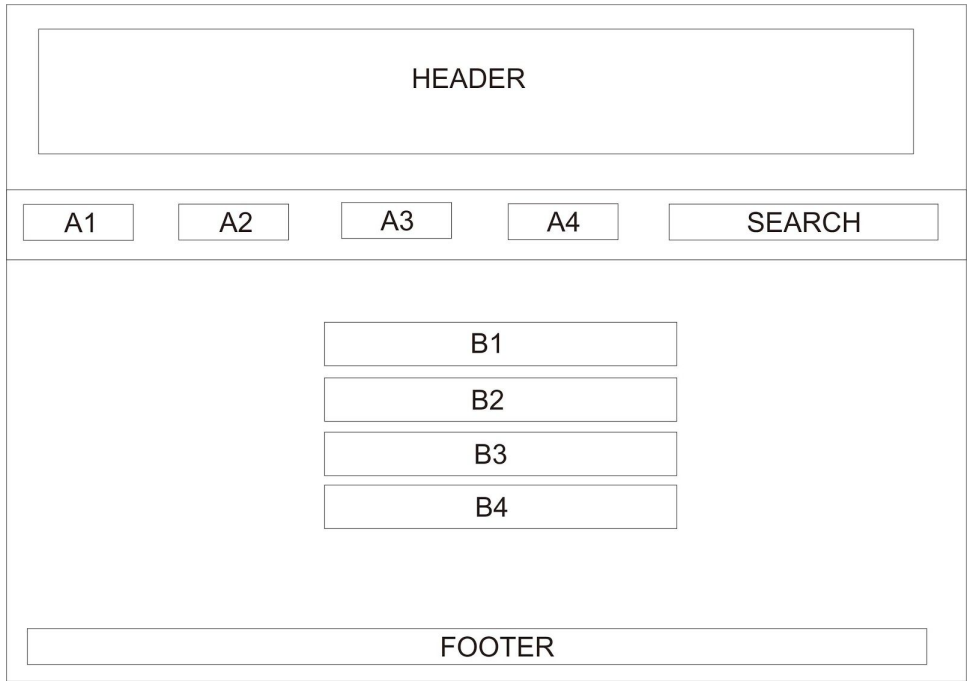

Figure 5. Registration Page Design

In this picture is a register page on the system intended for an admin by entering his email account and creating a password. In order to access the system.

Information:

A1. Homepage, Main web page

A2. About, this page contains information about the community and the history of its establishment.

A3. Profile, page about photos of social activities.

A4 Activities, this page contains information about donation activities.

B1. Full name

B2. E-mail

B3. The password

B4. Register 
5. Admin Page Design

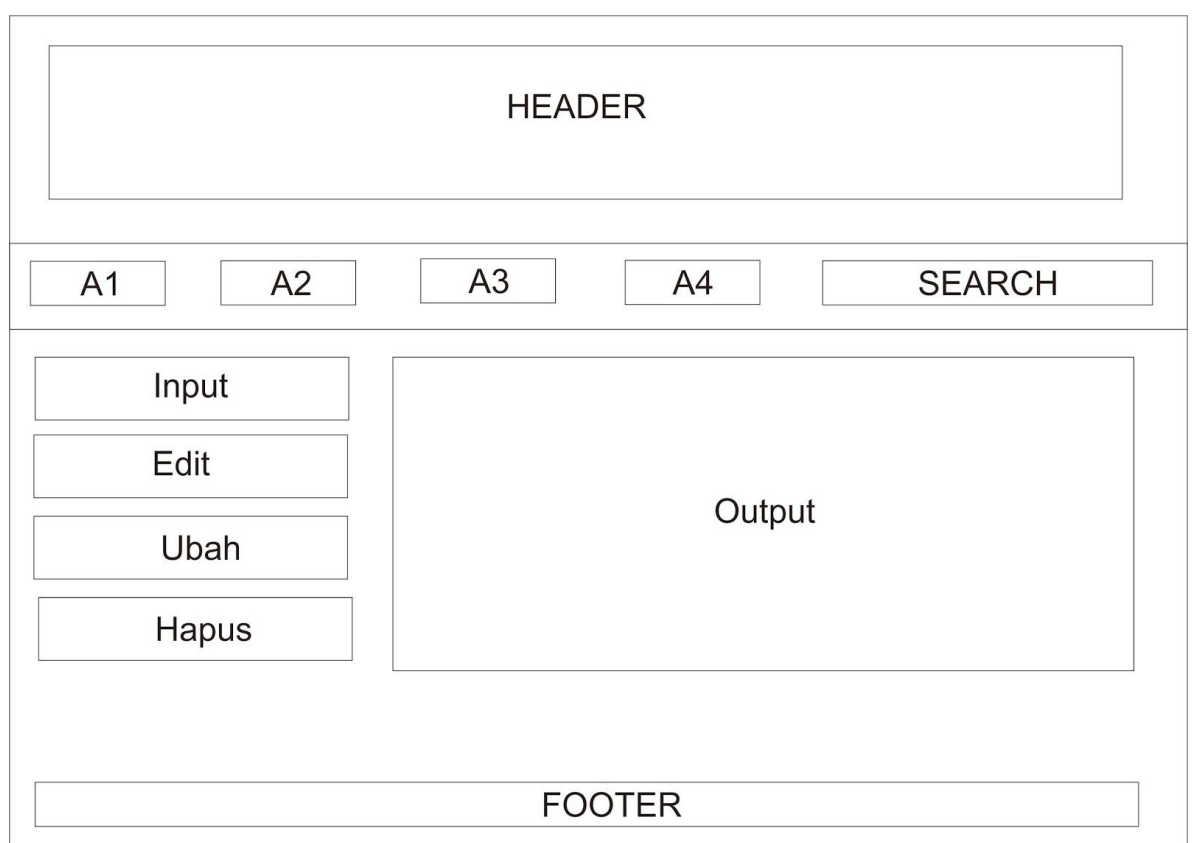

Figure 6. Designing the Admin Page

This page is for the admin on the website as a follow up process after the login process has been successful. In the admin system there are a number of menus to input, edit, change and delete data that can be used by the admin at any time as needed.

\subsubsection{User Interface}




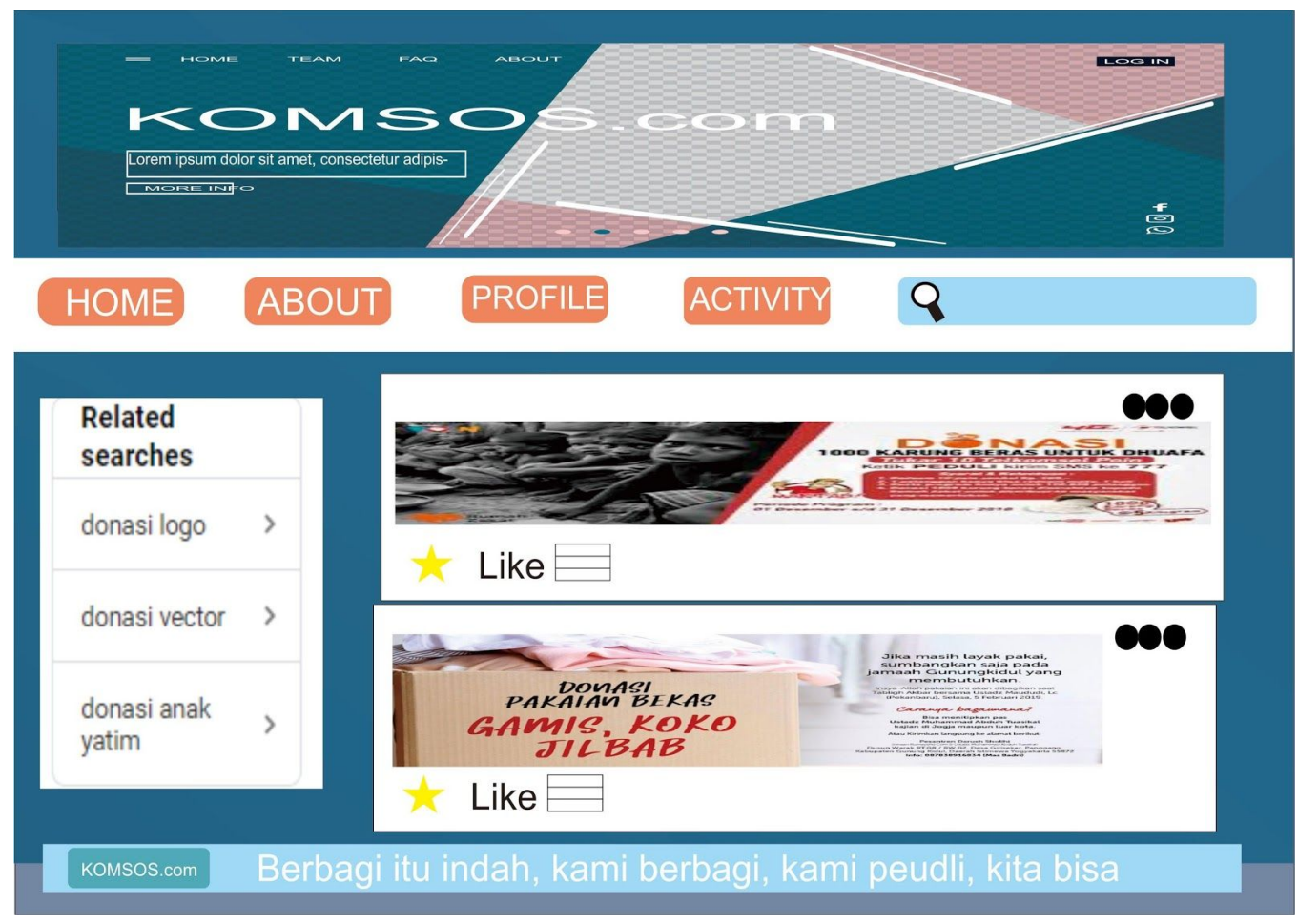

Figure 7. User Interface

\section{Conclusion}

The conclusions of this study are based on the analysis and design of web-based community information systems, the conclusions can be drawn as follows:

1. At this social community does not currently have an information system in the form of information dissemination or document processing as well as activity reports and reports on the use of funds.

2. This research resulted in a prototype of a website-based community activities information system that can be further implemented so as to produce a useful system and can share information so as to increase awareness among people.

3. With this website prototype can make it easier for users and visitors to get information on community activities, can cause interactive between users or visitors with administrators of social communities so that they can build suggestions and enter for the community going forward.

\section{References}

[1] Wahyuningrum, T., \& Januarita, D. (2014). Perancangan web e-commerce dengan metode Rapid Application Development (RAD) untuk produk unggulan desa. Semantik, 4(1).

[2] Sadewa, I., \& Siahaan, K. (2016). Analisis dan Perancangan Sistem Informasi Unit Kegiatan Mahasiswa (UKM) Berbasis Web pada Universitas Batanghari. Jurnal Manajemen Sistem Informasi, 1(2), 135-146.

[3] Sinaga, B. (2015). Perancangan Dan Pembuatan Sistem Informasi Forum Diskusi Mahasiswa/l Berbasis Web Di STMIK Pelita Nusantara Medan. Jurnal Mantik Penusa, 18(2).

[4] TRIYONO, M. (2018). SISTEM INFORMASI KOMUNITAS SOSIAL PADA OMAH AKSI DI KABUPATEN KUDUS BERBASIS WEB RESPONSIF (Doctoral dissertation, Universitas Muria Kudus). 
[5] Rancangan Bangun Aplikasi Komunitas Donor Darah Berbasis Web dan Android Dilengkapi Layanan Info Geografis 